\title{
Performance evaluation of two planter makes as affected by forward speeds
}

\author{
Mysara Ahmed Mohamed, Abdalla N. O. Kheiry*, Abbas E. Rahma and \\ Husam Aldeen Babiker Yousif
}

\author{
Department of Agricultural Engineering, College of Agricultural Studies, Sudan University of science and Technology, \\ Khartoum, Sudan. \\ *Corresponding author. Email: ginan99@yahoo.com
}

Copyright (C 2017 Mohamed et al. This article remains permanently open access under the terms of the Creative Commons Attribution License 4.0, which permits unrestricted use, distribution, and reproduction in any medium, provided the original work is properly cited.

Received 28th September, 2016; Accepted 17th November, 2016

\begin{abstract}
Two different makes of row crop planters were evaluated for performance by laboratory and field tests. The laboratory test was conducted to investigate the seed rate, uniformity of seed spacing and seed damage during operation, while the field test examined the effective field capacity, field efficiency, planter drive wheel slippage and fuel consumption, and two planting speeds were used $(5.5,8.5 \mathrm{~km} / \mathrm{hr})$. The experimental study was carried out at the farm of College of Agricultural Studies, where the soil is considered light clay soil. The field was tilled by discing once and harrowing once followed by leveling to prepare a uniform field for the planters work. An average weight of $17 \mathrm{~kg} / \mathrm{ha}$ and $31.5 \mathrm{~kg} / \mathrm{ha}$ of seeds were discharged during the test from Giad make and Rome make respectively. The seed spacing varying from the theoretical for the two planters, with a noticed minimum seed damage of $0.6 \%$ and $0.72 \%$ for Giad and Rome make planters respectively. Field evaluation results showed that planter make had significant effect $(p<0.05)$ on seed rate, seed spacing, fuel consumption and effective field capacity. Planting speed had a significant effect on seed rate, fuel consumption and effective field capacity. Interaction effect between planters and planting speed had significant effect $(p<0.05)$ on seed rate and fuel consumption only. The highest fuel consumption and driven wheel slippage were obtained with Giad make planter. Giad make planter gave lower field efficiency compared to Rome make planter at $5.5 \mathrm{~km} / \mathrm{hr}$ forward speed. From the study the two planters were able to effectively meter high seed rate with minimum damage to the seeds. Rome make gave better performance that resulted in lower fuel consumption, wheel slippage and high field efficiency.
\end{abstract}

Key words: Effective field capacity, row crop planter, wheel slippage.

\section{INTRODUCTION}

Farm machinery is an important element for agricultural development and crop production in many developed countries. The use of machines for agricultural operations has been one of the outstanding developments in the global agriculture during the last decade (Abdalla, 2007). The planting operation is one of the most important cultural practices associated with crop production. It should result in a plant stand at the desired density that emerges quickly and uniformly. The advantage of using precision planters includes saving seeds, fewer working hours, achieves more uniform spacing in the row and the depth of planting, and for these reasons it follows that the crop will be uniform in height and strength which is a prerequisite for high yields. Proper selection of planting machine that suits available power, crop type and soil condition is important to reduce energy required (Hunt, 1995). Planters can give different types of precision and distribution pattern, depending on the machine that is being used (Abdalla 2007). He classified the planting equipments into precision planters, grain drills, broadcasters and vegetable planters. Abdalla (2007) stated that machine performance may be studied and evaluated in the field through different parameters such as field capacity, wheel slippage, fuel consumption, seed 
rate and seed spacing.

A manually operated cowpea precision planter was developed by Oduma et al (2014) and evaluated for performance by laboratory and field investigation. The planter minimum seed damage was recorded as $2.34 \%$ during laboratory testing, the field efficiency of $71.71 \%$ and average field capacity of $0.260 \mathrm{ha} / \mathrm{hr}$ were obtained from the planter field test. Bamgboye and Mofolasayo (2006) developed a manually operated two row Okra planter. The field efficiency and field capacity were $71.75 \%$ and $0.36 \mathrm{ha} / \mathrm{hr}$ respectively with low average seed damage of $3.51 \%$. Gupta and Herwanto (1992) designed and fabricated a direct paddy planting machine. The machine had a field capacity of about $0.5 \mathrm{ha} / \mathrm{hr}$ at a forward speed of $0.81 \mathrm{~m} / \mathrm{s}$ and there was no damage caused by the metering mechanism for soaked seeds, though 3\% damage was recorded for pre germinated seeds (Gupta and Herwanto (1992). A two row ridge planter was developed for planting winter maize and evaluated in the field over an area of 0.4 ha by Gill et al (2014). The capacity of the planter was $0.10 \mathrm{ha} / \mathrm{hr}$ at a forward speed of $2.5 \mathrm{~km} / \mathrm{hr}$ and average seed spacing was $19 \mathrm{~cm}$. Raghavendra and Veerangeouda (2013) developed and evaluated a ridge planter for cotton. The crop machine and operational parameters were identified and selected. The forward speed used was $1.25 \mathrm{~m} / \mathrm{s}$, the average fuel consumption was $3.83 \mathrm{l} / \mathrm{hr}$ and the field capacity was $0.89 \mathrm{ha} / \mathrm{hr}$ with afield efficiency of $73.55 \%$. A tractor mounted pneumatic planter was developed and evaluated for laboratory and field testing (Kumar et al., 2015). It was seen that the machine can be used as a precision planter for different crops. During field testing for cotton, the effective field capacity was found to be $0.55 \mathrm{ha} / \mathrm{hr}$, field efficiency $76 \%$ and fuel consumption measured was $4.43 \mathrm{I} / \mathrm{hr}$. Pandey and Majumdar (1997) developed a tractor mounted seed planter for growing groundnut. The use of planter had reported an increase in crop yield with a $0.63 \mathrm{ha} / \mathrm{hr}$ and $78 \%$ field capacity and field efficiency respectively. A new power operated six row planter was developed and evaluated by Ashoka et al (2012) for its performance by conducting laboratory tests and field trials. Studies revealed that the percentage damage was found to be $2.5 \%$. In the field studies, the planter had the field capacity of $0.25 \mathrm{ha} / \mathrm{hr}$ and seed to seed spacing of 100 to $140 \mathrm{~mm}$ with the overall planter efficiency of $86.8 \%$. Kumar et al (2015) conducted a performance evaluation of a tractor mounted planter for sorghum in dry land in both laboratory and actual field condition. They found that average value of plant to plant spacing; actual field capacity and field efficiency to be $101 \mathrm{~mm}, 0.773 \mathrm{ha} / \mathrm{hr}$ and $79.7 \%$ respectively. Kumarand Samastipur (2011) developed a multi crop inclined plate planter for sowing different type of crops. He reported that the wheel slippage was in tolerable limit as it recorded $4.53 \%$ with the field capacity and field efficiency of $0.23 \mathrm{ha} / \mathrm{hr}$ and $51.1 \%$ respectively.

Planting operation in most agricultural schemes of
Sudan is carried out manually for most of the crops which lead to delay of the subsequent operation and finally affect the crop yield. Recently, most of farm machines are imported and they are not specially designed to operate in the various Sudan regions and states and specific tropical conditions. In general, they are imported without any standardized testing and evaluation. In addition, it was realized that many of locally manufactured agricultural implements in Sudan are of substandard quality. The low quality machinery leads to financial losses and at times is also unsafe for operation in the field. The two planters used in this study were Giad planter make (Sudanese make) and Rome (Brazilian make) type. Each of them consist of four planting units equipped with fertilizer distributors and both of them were tractor mounted.

The objective of this study was to determine the influence of planter make and forward speeds on laboratory and field performance considering seed rate, seed spacing, seed damage, effective field capacity, field efficiency, drive wheel slippage and fuel consumption.

\section{MATERIALS AND METHODS}

\section{Experimental site}

The experiment was conducted on a selected area of 70 $x 23 \mathrm{~m}^{2}(0.161 \mathrm{ha})$ in the farm of the College of Agricultural Studies. Soil samples were collected at the depth of 0 to $40 \mathrm{~cm}$ to determine soil texture. Soil texture was found to be light clay soil. The soil physical properties of the experimental site are shown in Table 1. The experimental site prior to this study had been under disk plough and harrowing operations.

\section{Experimental design and layout}

The area selected was divided into sub-plots in the farm. Two different makes of row crop planters were evaluated on basis of seed spacing, seed damage and seed rate for laboratory evaluation and of effective field capacity, field efficiency, rear wheel slippage and fuel consumption for field evaluation. A two combination of planters (Rome planter and Giad make planter equipped with fertilizers drill) and two planting speeds (5.5 and $8.5 \mathrm{~km} / \mathrm{hr}$ ) were used.

Massey Ferguson 440 tractor was used to pull the two planters in the field separately. The two planters used consist of four planting units, equipped with fertilizer distributors and both of them were tractor mounted. Other tools and implements which were used in the study include: steel chain, meter tape $(50 \mathrm{~m})$, ranging poles, stop watch, hundred liters graduated cylinder, fuel jerrycan, a piece of chalk and small size broad bean seeds. The experiment was arranged in a split plot 
Table 1. Some soil physical properties of the experimental site.

\begin{tabular}{|c|c|c|c|c|c|c|}
\hline \multirow{2}{*}{ Depth/cm } & \multirow{2}{*}{$\begin{array}{c}\text { Bulk density } \\
\text { gm/cm3 }\end{array}$} & \multirow{2}{*}{$\begin{array}{l}\text { Moisture } \\
\text { content \% }\end{array}$} & \multicolumn{3}{|c|}{ Particle size distribution } & \multirow{2}{*}{$\begin{array}{l}\text { Textural } \\
\text { class }\end{array}$} \\
\hline & & & Clay & Silt & Sandy & \\
\hline $0-20$ & 1.77 & 11.52 & 31 & 57.1 & 11.9 & Silt clay \\
\hline $20-40$ & 1.54 & 15.2 & 57.1 & 21.4 & 21.4 & Clay \\
\hline
\end{tabular}

Table 2. Some specifications of planters.

\begin{tabular}{lll}
\hline Specifications & Row Crop planter & Row Crop planter \\
\hline Mark & ROME & ATESPAR \\
Make & Brazil & Giad (Sudan) \\
Width of cut & $240 \mathrm{~cm}$ & $240 \mathrm{~cm}$ \\
Number of units & 4 & 4 \\
Weight & $300 \mathrm{~kg}$ & $450 \mathrm{~kg}$ \\
Hitching & $3-$ point linkage & 3- point linkage \\
Others & With fertilizer attached & With fertilizer attached \\
\hline
\end{tabular}

design with forward speed assigned to the main plots while planter makes were distributed to the subplots with three replicates. The specifications of the planters are presented in Table 2.

\section{Experimental procedures}

\section{The performance of planters}

The different performance evaluation tests of the row crop planters involved:

1. Laboratory test to check the seed placement spacing, seed rate and seed damage.

2. Field performance trials to evaluate viability of the machine and to measure effective field capacity (EFC), field efficiency (Feff.), fuel consumption and wheel slippage.

\section{Calibration}

The two planters were load with $2 \mathrm{kgs}$ of broad been seeds. Each of the planters drive wheel was held up (jacked up) to free the drive wheels. A mark was made on each of the drive wheels to serve as reference points to count the number of revolutions when turned. A polyethelyne bag was placed on each of the discharge tube to collect the seeds discharged. The drive wheels were rotated 40 times. A stop watch was used to measure the time taken to complete the revolutions. The seeds in each bag were weighed on a balance and the procedure was repeated three times. For the laboratory test, the planter units were raised separately and the ground wheel was rotated manually for 40 revolutions. The total number of seeds metered and spacing was calculated.

\section{Seed damage test}

The test for seed damaged percentage was done with machines held in a similar position as explained above. The $0.5 \mathrm{~kg}$ of seeds was loaded into each hopper. The wheels were rotated 40 times in turns and the time taken to complete the revolution was recorded with stop watch. The seeds discharged from each tube were observed for any external damage and the procedure was repeated for three times. The following relationship was used to calculate the seed damage percentage:

Damage $\%=\frac{\mathrm{Nd}}{\mathrm{Nt}} \times 100 \%$

Eqn. 1

Where: $N_{d}=$ total number of damaged seeds, $N_{t}=$ total number of seeds.

\section{Field test}

The field trials were conducted for the determination of effective field capacity, field efficiency, fuel consumption and wheel slippage. Investigation involved continuous observation and timing of each activity and time losses for turning at head land and adjustment.

\section{Fuel consumption measurement}

The fuel tank of MF-440 tractor was filled up to its top level before field testing. After planting, the tractor engine was stopped and the fuel tank was refilled up to the same level with the graduate cylinder to determine the quantity 
Table 3. Planters laboratory test.

\begin{tabular}{lcc}
\hline Machine type test & Giad & Rome \\
\hline Seed rate $(\mathrm{kg} / \mathrm{ha})$ & 17 & 31.5 \\
Seed spacing $(\mathrm{cm})$ & 10.3 & 9.7 \\
Seed damage $(\%)$ & 0.6 & 0.72 \\
\hline
\end{tabular}

Table 4. Analysis of variance table for seed rate.

\begin{tabular}{lccccc}
\hline Source & DF & SS & MS & F & P \\
\hline Rep & 2 & 53026.2 & 26513.1 & & \\
Speed & 1 & 611105 & 611105 & 22.07 & 0.0424 \\
Error rep*speed & 2 & 55371.2 & 27685.6 & & \\
Machine & 1 & $1.88 \mathrm{E}+09$ & $1.88 \mathrm{E}+09$ & 75455.2 & 0 \\
speed $^{*}$ machine & 1 & 680680 & 680680 & 27.28 & 0.0064 \\
Error rep*speed*machine & 4 & 99805.3 & 24951.3 & & \\
Total & 11 & $1.88 \mathrm{E}+09$ & & & \\
\hline
\end{tabular}

$\mathrm{DF}$, degrees of freedom in the source, SS, sum of squares due to the source, MS, mean sum of squares due to the source, F, F-statistic, P, P-value.

of diesel fuel needed to refill the tractor tank up to the same level. Fuel consumption per hectare was calculated by the following formula:

$\mathrm{TF}=\frac{\mathrm{F}}{\mathrm{A} \times 1000}$

Eqn. 2

Where: TF $=$ Total fuel consumed (lit/ha), $F=$ Fuel consumed (mlit), $A=$ Area covered (ha).

\section{Measurement of wheel slippage}

The measurement of wheel slippage was done for drive wheel of planters. At first, the distance traveled by planter for 10 revolutions of the drive wheel was recorded without load. Then, after three observations were taken for the same number of revolutions when operated with load, the average of these observations was calculated. The percentage wheel slippage of two planters was then calculated as follow:

Slippage $\%=\frac{\mathrm{L} 1-\mathrm{L} 2}{\mathrm{~L} 1}$ Eqn. 3

Where: $L_{1}=$ actual distance traveled (without loaded) $(m)$, $\mathrm{L}_{2}=$ theoretical distance traveled (with load) $(\mathrm{m})$

\section{Effective field capacity and field efficiency}

The time was recorded and the planting width was determined using the steel tape. Then, the effective field capacities and field efficiencies were calculated as follows:

$$
\begin{aligned}
& \text { Effective field capacity (EFC) ha/hr }=\frac{\text { Plot area }(20 \mathrm{~m})}{\text { Total time require to cover the plot (hr) }} \text { Eqn (4) } \\
& \text { Theoretical field capacity }(\mathrm{TFC})=\frac{\text { planter width } \times \text { speed }}{\text { Constant }(10)} \\
& \text { Field efficiency }=\frac{\text { Effective field capacity }}{\text { Theoretical field capacity }} \times 100 \%
\end{aligned}
$$

\section{RESULTS AND DISCUSSION}

\section{Effects of planter make and different speeds on seed rate, seed spacing and seed damage percentage}

Planter's laboratory test (seed rate, seed spacing and seed damage \%) for the two makes of planter were shown in Table 3.

Analysis of variance given in Tables 4 and 5 shows that planter make had a significant effect $(p<0.05)$ on seed rate and seed spacing while forward speed had a significant effect on seed rate but the seed spacing was 
Table 5. Analysis of variance table for seed spacing.

\begin{tabular}{llllll}
\hline Source & DF & SS & MS & F & P \\
\hline Rep & 2 & 43.062 & 21.531 & & \\
Speed & 1 & 24.941 & 24.941 & 0.92 & 0.4390 \\
Error rep*speed & 2 & 54.312 & 27.156 & & \\
Machine & 1 & 197.641 & 197.641 & 6.86 & 0.0588 \\
speed $^{*}$ machine & 1 & 33.667 & 33.667 & 1.17 & 0.3404 \\
Error rep*speed ${ }^{*}$ machine & 4 & 115.187 & 28.797 & & \\
Total & 11 & 468.809 & & & \\
\hline
\end{tabular}

$D F$, degrees of freedom in the source, SS, sum of squares due to the source, MS, mean sum of squares due to the source, F, F-statistic, P, P-value.

Table 6. Planters Field test for all observed parameters at different field speeds.

\begin{tabular}{lcccc}
\hline Machine type & \multicolumn{2}{c}{ Giad } & \multicolumn{2}{c}{ Rome } \\
\hline Speed & $8.5 \mathrm{~km} / \mathrm{hr}$ & $5.5 \mathrm{~km} / \mathrm{hr}$ & $8.5 \mathrm{~km} / \mathrm{hr}$ & $5.5 \mathrm{~km} / \mathrm{hr}$ \\
Effective field capacity (ha/hr) & 2.1 & 1.26 & 2.1 & 1.3 \\
Efficiency (\%) & 88 & 84 & 88 & 86 \\
Fuel consumption (litlha) & 3.5 & 3.15 & 3.2 & 2.1 \\
Wheel slippage (\%) & 3.4 & 2.8 & 2.8 & 2.4 \\
\hline
\end{tabular}

Table 7.Analysis of variance table for effective field capacity.

\begin{tabular}{|c|c|c|c|c|c|}
\hline Source & DF & SS & MS & $\mathbf{F}$ & $\mathbf{P}$ \\
\hline Rep & 2 & 0.0487 & 0.0243 & & \\
\hline Speed & 1 & 11.8207 & 11.8207 & 35.95 & 0.0267 \\
\hline Error rep*speed & 2 & 0.6577 & 0.3288 & & \\
\hline Machine & 1 & 0.0007 & 0.0007 & 0.01 & 0.9257 \\
\hline speed*machine & 1 & 0.0007 & 0.0007 & 0.01 & 0.9257 \\
\hline Error rep*speed ${ }^{*}$ machine & 4 & 0.2743 & 0.0686 & & \\
\hline Total & 11 & 12.8026 & & & \\
\hline
\end{tabular}

$\mathrm{DF}$, degrees of freedom in the source, SS, sum of squares due to the source, MS, mean sum of squares due to the source, F, F-statistic, P, P-value.

not influenced by the two forward speeds. The interaction of forward speed and planter make were statistically significant for seed rate only $(p<0.05)$.

It is observed (Table 3 ) that Rome make recorded 31.5 $\mathrm{kg} / \mathrm{ha}$ as seed rate while Giad make recorded $17 \mathrm{~kg} / \mathrm{ha}$. Seed spacing for Giad make was $10.3 \mathrm{~cm}$ while for Rome type was $9.7 \mathrm{~cm}$. The two planters showed less deviation from the recommended spacing of $10 \mathrm{~cm}$. The average spacing obtained was slightly differing from the recommended spacing for the two planters. The two planters registered the minimum deviation of three percent from the recommended $10 \mathrm{~cm}$ seed spacing. This may be due to the light weight and size of seeds used and the variation in the time taken to the seed to reach the final placement point. Seed damage percent $0.6 \%$ and $0.72 \%$ for Giad and Rome make planter respectively) for the two makes was less than the findings obtained by Oduma et al (2014) and Gupta and Herwanto (1992) $(2.34 \%$ and $3 \%$ respectively). Probably, the two average values of the percentage seed damage $(0.6 \%$, $0.72 \%$ respectively for Giad and Rome make) observed in this work was due to the low speed at which the planter wheels were rotated during the laboratory test. The damage is very low as compared to Ashoka et al (2012) and Bamgboye and Mofolasayo (2006).

\section{Effects of planter make and forward speed on effective field capacity and machine efficiency}

The differences in field capacity between two make of planters were statistically not significant but it was statistically significant $(P<0.05)$ between two different forward speed (Table 7).

The effective field capacity (ha/hr) and field efficiency percentage for the two planters at the two different speeds were shown in Table 6. It was clear that at all different speeds there was no much variation in respect 
Table 8. Analysis of variance table for field efficiency.

\begin{tabular}{lccccc}
\hline Source & DF & SS & MS & F & P \\
\hline Rep & 2 & 9.500 & 4.750 & & \\
Speed & 1 & 90.750 & 90.750 & 0.64 & 0.5089 \\
Error rep*speed & 2 & 285.500 & 142.750 & & \\
Machine & 1 & 0.750 & 0.750 & 0.04 & 0.8550 \\
speed $^{*}$ machine $_{\text {Error rep*speed }}^{*}$ machine & 1 & 0.750 & 0.750 & 0.04 & 0.8550 \\
Total & 4 & 79.000 & 19.750 & & \\
\hline
\end{tabular}

$\mathrm{DF}$, degrees of freedom in the source, SS, sum of squares due to the source, MS, mean sum of squares due to the source, F, F-statistic, P, P-value.

Table 9.Analysis ofvariance table for wheel slippage.

\begin{tabular}{lccccc}
\hline Source & DF & SS & MS & F & P \\
\hline Rep & 2 & 1.09500 & 0.54750 & & \\
Speed & 1 & 0.60750 & 0.60750 & 1.88 & 0.3036 \\
Error rep*speed & 2 & 0.64500 & 0.32250 & & \\
Machine & 1 & 0.90750 & 0.90750 & 3.86 & 0.1208 \\
speed $^{*}$ machine & 1 & 0.06750 & 0.06750 & 0.29 & 0.6204 \\
Error rep*speed ${ }^{*}$ machine & 4 & 0.94000 & 0.23500 & & \\
Total & 11 & 4.26250 & & & \\
\hline
\end{tabular}

$\mathrm{DF}$, degrees of freedom in the source, SS, sum of squares due to the source, MS, mean sum of squares due to the source, F, F-statistic, P, P-value.

of effective field capacity for the two planters and this may be due to the same width of the planters working with the same speeds. The results indicated that the highest effective field capacity was recorded by two makes at speed $8.5 \mathrm{~km} / \mathrm{hr}(2.1 \mathrm{ha} / \mathrm{hr})$ while the lowest Giad planter make at speed $5.5 \mathrm{~km} / \mathrm{hr}$ recorded the lowest values of effective field capacity (1.26 ha/hr). This may be attributed to an increase in slippage of an implement which led to decrease in implement speed leading to decrease in effective field capacity. Aalbushari (2016) reported that a reduction in wheel slippage resulted in increased implements speed. For the field efficiency, the two planters recorded the same value $88 \%$ at $8.5 \mathrm{~km} / \mathrm{hr}$ while it was $84 \%$ and $86 \%$ at speed 5.5 $\mathrm{km} / \mathrm{hr}$ for Giad and Rome planter respectively.

Analyses of variance (Table 8) show no significant difference between the field efficiency of the two planters at the different speeds. This was due to the highest values of effective field capacity at speed $8.5 \mathrm{~km} / \mathrm{hr}$. As shown in Table 6 , the average value of field efficiency obtained from the field was $88 \%$ for the two planters. This shows a satisfactory performance as it is above the range of values obtained for planting operation by Raghavendra (2013 and Ashoka et al. (2012).

\section{Effect of planter type and forward speeds on fuel consumption and planters wheel slippage}

The statistical analysis (Table 9) shows that there are no significant differences $(P>0.05)$ in wheel slippage pairwise differences among the two various makes of planter. Table 6 shows the effect of planter makes on wheel slippage. It could be observed that, Rome planter recorded lower values of slippage at the two forward speeds compared to Giad make by $14.3 \%$ for speed 5.5 $\mathrm{km} / \mathrm{hr}$ and by $17.6 \%$ for speed $8.5 \mathrm{~km} / \mathrm{hr}$. It was also noticed that the high values of slippage percentage (Table 6) for the two makes of planter were $3.4 \%$ and $2.8 \%$ which is well within the recommended value of $5.7 \%$ reported by Raghavendra et al. (2013).

Over the course of the study, the effect of two different planter makes was highly significant $(P<0.05)$ on fuel consumption. While there was no significant difference in fuel consumption at the two different speeds (Table 10), Table 6 shows the rate of fuel consumption for two planters at different forward speeds was highly significant. It was observed that the Rome planter make recorded a lower value of fuel consumption 2.1 Lit/ha under speed of $5.5 \mathrm{~km} / \mathrm{hr}$ while Giad make planter showed high rate of fuel consumption of $3.5 \mathrm{~L} / \mathrm{ha}$ at 8.5 $\mathrm{km} / \mathrm{hr}$ field speed compared to Rome planter that used $3.2 \mathrm{~L} / \mathrm{ha}$ at $8.5 \mathrm{~km} / \mathrm{hr}$. This was due to the big size of the fertilizer unit equipped with the Giad planter.

\section{Conclusion}

Giad and Rome Brazilian makes planters were evaluated and tested by laboratory and field performance test under 
Table 10 .Analysis of variance Table for fuel consumption.

\begin{tabular}{lccccc}
\hline Source & DF & SS & MS & F & P \\
\hline Rep & 2 & 0.00065 & 0.00033 & & \\
Speed & 1 & 0.01080 & 0.01080 & 13.94 & 0.0649 \\
Error rep*speed & 2 & 0.00155 & 0.00078 & & \\
Machine & 1 & 0.01080 & 0.01080 & 43.20 & 0.0028 \\
speed $^{*}$ machine $_{\text {Error rep*speed*machine }}^{*}$ & 1 & 0.00270 & 0.00270 & 10.80 & 0.0303 \\
Total & 4 & 0.00100 & 0.00025 & & \\
\hline
\end{tabular}

$\mathrm{DF}$, degrees of freedom in the source, SS, sum of squares due to the source, MS, mean sum of squares due to the source, F, F-statistic, P, P-value.

field conditions. Laboratory testing was done for seed rate, seed spacing and seed damage. Effective field capacity, field efficiency, wheel slippage and fuel consumption were measured on actual field conditions. The seed rate was found to be $17 \mathrm{~kg} / \mathrm{ha}$ for Giad make and $31.5 \mathrm{~kg} / \mathrm{ha}$ for Rome make. The two planters showed less deviation from the recommended and theoretical spacing $(10 \mathrm{~cm})$. Seed damage percentage was found less than the range obtained by other researchers $(2.5$ to $3.51 \%$ ). Highest percentage of field efficiency was found to be $88 \%$ for the two planters at the same speed ( 8.5 $\mathrm{km} / \mathrm{hr}$ ). The lower rate of fuel consumption and wheel slip were found to be $2.1 \mathrm{~L} / \mathrm{ha}$ and $2.4 \%$ respectively when using Rome planter at $5.5 \mathrm{~km} / \mathrm{hr}$. From the study, the two planters were able to effectively meter high seed rate with minimum damage to the seeds and the relative ease with which the planters are adjusted and maneuvered in the field suits the technical knowhow of the average beans farmer.

\section{CONFLICT OF INTEREST}

The authors declare that they have no conflict of interest.

\section{REFERENCES}

Abdalla, A. N. O. (2007). Comparison of two row planting machine performance as effected by forward speed under two soil condition .M.SC. Thesis University of Khartoum.

Albushari. S. A. (2016). Effect of different seed drill covering devices on forage sorghum seed emergence and machine performance.A research project, college of Agriculural Studies, Sudan university of Science and Technology (SUDAN).

Ashoka, H. G., Jayanthi, B., \& Prashantha, G. H. (2012). Performance evaluation of power drown six row ground nut planter. International journal of agricultural engineering, (5)2, 123-126.
Bamgboye, A. I., \& Mofolasayo, S. A. (2006). Performance evaluation of a two row okra planter. Agricultural Engineering International: CIGR Journal, 8, 1-10.

Gill, A., N., Anjum, A. G., \& Igbal, M. (2014). Design Modification and Field performance of two Row maize planter. IJDR, 4, 1336-1340.

Gupta, C. P., \& Herwanto, T. (1992). Design and development of a direct paddy seeder. Agricultural Mechanization in Asia, Africa and Latin America, 23(1), 23-27.

Hunt, D. R. (1995). Farm power and machinery management seventh ed. lowa state university press Amis.U.S.A. Pp. 82 90.

Kumar, K., Naoresh N. K., \& Ojha, T. P. (2015). Designconstruction and performance of manually - operated seeding attachment for an animal drawn cultivation. Agricultural Mechanization in Asia, Africa and Latin America, 17(2), 35-38.

Kumar, R., Adamala, S., Rajwade, Y. A., \& Singh, H. V. (2015). Performance evaluation of a tractor mounted pneumatic planter for sorghum in dryland. African Journal of Agricultural Research, 10(39), 3767-3772.

Kumar, S. N., \& Samastipur, B. (2011). Performance evaluation of bullock drawn multi crop inclined plate planter. Internat. $J$. Agric. Engg., 4(2), 193-199.

Oduma, O., Ede, J. C., Igwe, J. E. (2014). Development and performance evaluation of a manually operated Cow pea precision planter. International journal of engineering and technology, 4(12), 693- 699

Pandey, M. M., \& Majumdar K. L. (1997). Tractor- mounted seed planter for sowing ground nut. Farm machinery research digests. All India coordinated project on farm implement and machinery, ICAR.

Raghavendra, M., \& Veerangeouda, K. V. (2013). Development and evaluation of ridge planter for cotton. Karnataka Journal of Agricultural Sciences, 26(1), 88-91. 